\title{
Gadolinium chloride elicits apoptosis in human osteosarcoma U-2 OS cells through extrinsic signaling, intrinsic pathway and endoplasmic reticulum stress
}

\author{
YUH-FENG TSAI $^{1,2}$, CHING-WEN HUANG $^{1}$, JO-HUA CHIANG $^{3}$, FUU-JEN TSAI $^{4,5}$, \\ YUAN-MAN HSU ${ }^{6}$, CHI-CHENG LU ${ }^{7}$, CHEN-YU HSIAO $^{1}$ and JAI-SING YANG ${ }^{8}$
}

${ }^{1}$ Department of Diagnostic Radiology, Shin-Kong Wu Ho-Su Memorial Hospital, Taipei; ${ }^{2}$ School of Medicine,

Fu-Jen Catholic University, New Taipei; ${ }^{3}$ Department of Nursing, Chung-Jen Junior College of Nursing,

Health Sciences and Management, Chiayi County; ${ }^{4}$ Human Genetic Center, China Medical University Hospital, Taichung;

${ }^{5}$ School of Post-Baccalaureate Chinese Medicine, China Medical University, Taichung; ${ }^{6}$ Department of Biological Science and Technology, China Medical University, Taichung; ${ }^{7}$ School of Nutrition and Health Sciences, Taipei Medical University, Taipei;

${ }^{8}$ Department of Medical Research, China Medical University Hospital, China Medical University, Taichung, Taiwan, R.O.C.

Received May 25, 2016; Accepted October 10, 2016

DOI: $10.3892 / o r .2016 .5174$

\begin{abstract}
Gadolinium (Gd) compounds are important as magnetic resonance imaging (MRI) contrast agents, and are potential anticancer agents. However, no report has shown the effect of gadolinium chloride $\left(\mathrm{GdCl}_{3}\right)$ on osteosarcoma in vitro. The present study investigated the apoptotic mechanism of $\mathrm{GdCl}_{3}$ on human osteosarcoma U-2 OS cells. Our results indicated that $\mathrm{GdCl}_{3}$ significantly reduced cell viability of U-2 OS cells in a concentration-dependent manner. $\mathrm{GdCl}_{3}$ led to apoptotic cell shrinkage and DNA fragmentation in U-2 OS cells as revealed by morphologic changes and TUNEL staining. Colorimetric assay analyses also showed that activities of caspase- 3 , caspase- 8 , caspase- 9 and caspase- 4 occurred in $\mathrm{GdCl}_{3}$-treated U-2 OS cells. Pretreatment of cells with pan-caspase inhibitor (Z-VAD-FMK) and specific inhibitors of caspase-3/-8/-9 significantly reduced cell death caused by $\mathrm{GdCl}_{3}$. The increase of cytoplasmic $\mathrm{Ca}^{2+}$ level, ROS production and the decrease of mitochondria membrane potential $(\Delta \Psi \mathrm{m})$ were observed by flow cytometric analysis in U-2 OS cells after $\mathrm{GdCl}_{3}$ exposure. Western blot analyses demonstrated that the levels of Fas, FasL, cytochrome $c$, Apaf-1, GADD153 and GRP78 were upregulated in $\mathrm{GdCl}_{3}$-treated U-2 OS cells. In conclusion, death receptor, mitochondria-dependent and endoplasmic reticulum (ER) stress pathways contribute to
\end{abstract}

Correspondence to: Dr Chen-Yu Hsiao, Department of Diagnostic Radiology, Shin-Kong Wu Ho-Su Memorial Hospital, No. 95 Wen-Chang Road, Taipei 11101, Taiwan, R.O.C.

E-mail: leo_eraser@yahoo.com.tw

Key words: $\mathrm{GdCl}_{3}$, osteosarcoma U-2 OS cells, apoptosis, endoplasmic reticulum stress
$\mathrm{GdCl}_{3}$-induced apoptosis in U-2 OS cells. $\mathrm{GdCl}_{3}$ might have potential to be used in treatment of osteosarcoma patients.

\section{Introduction}

Osteosarcoma is the most common type of malignant bone tumor in children and teenagers $(1,2)$. Unfortunately, less than $50 \%$ of patients living beyond 10 years results from the response to the current preferred treatment of preoperative adjuvant chemotherapy followed by surgery (3). Furthermore, no reliable predictors are applied to guide the choice or the intensity of the chemotherapy (4). Currently, there is still a limited role in radiotherapy which should be reserved for inoperable situations. Doxorubicin, cisplatin, ifosfamide and high-dose methotrexate with leucovorin rescue are recognized as the most effective agents against osteosarcoma, but the ideal combination remains to be defined and needs to further well investigated (5). Targeting apoptosis (programmed cell death type I) is a promising approach in the fight against osteosarcoma (6). Therefore, the induction of cell apoptosis is one of best strategies for treating osteosarcoma and multiple cancers $(7,8)$.

Apoptotic function is associated with several diseases, including cancer genesis, and diabetes, and this process is considered a critical element of cancer prevention and therapy $(6,9)$. The three main pathways (death receptor signal, mitochondrial regulation and endoplasmic reticulum stress) contribute to apoptotic signaling (10-12). The death receptor signal is induced by the binding of extrinsic signals to surface receptors, resulting in activation of caspase- 8 followed by the activation of caspase-3/-7 (10,11). The mitochondrial pathway is regulated by endoplasmic reticulum (ER) various damage stimuli, which increase reactive oxygen species (ROS) and subsequent damage DNA. These stresses disrupt mitochondrial membrane potential $(\Delta \Psi \mathrm{m})$ to cause cells to undergo apoptosis cascade $(11,13)$. Accumulation of unfolded/misfolded 
proteins elicits ER-specific pathway aggregating in ER by excessive protein traffic (12). The hallmarks of ER stress are known to stimulate the protein level of growth arrest- and DNA damage-inducible gene 153 (GADD153), glucose-regulated protein 78 (GRP78), GRP94 and activating transcription factor 4 (ATF-4), which can induce intracellular $\mathrm{Ca}^{2+}$ level to activate calpain and caspase- 12 and/or caspase- 4 molecules $(13,14)$. Therefore, induction of apoptosis by a novel target in these pathways is an attractive approach to fight the tumor cell system.

The rare earth metals of Lanthanides (Lns) exhibit a variety of physical or chemical properties and have been applied in agriculture and medicine for a long time $(15,16)$. Gadolinium (Gd), a member of Lns family, has multi-biological effects on organisms (17), and its compounds have important applications in magnetic resonance imaging (MRI) as contrast medium and are potential anticancer agents $(18,19)$. In clinic, chelates of $\mathrm{Gd}$ such as gadobenate dimeglumine (MultiHance) are used as contrast agent in MRI (20). Gadolinium texaphyrin complex (MGd) was evaluated in phase III clinical trials for treating brain metastases of non-small cell lung cancer (21). The Kupffer cell inhibitor gadolinium chloride $\left(\mathrm{GdCl}_{3}\right)$ has been demonstrated to inhibit human hepatoma HepG2 cell proliferation $(22,23)$. It was also shown that $\mathrm{GdCl}_{3}$ induces HepG2 cell apoptosis through mitochondria-dependent pathway (22). Hence, the present study investigated the effects of $\mathrm{GdCl}_{3}$-induced apoptosis and the underlying mechanisms on human osteosarcoma $\mathrm{U}-2$ OS cells. The experimental data indicated that $\mathrm{GdCl}_{3}$ triggered U-2 OS cell apoptosis through death receptor-, mitochondria- and ER stress-dependent pathways.

\section{Materials and methods}

Chemicals and reagents. Gadolinium chloride $\left(\mathrm{GdCl}_{3}\right)$, 3-(4,5-dimethylthiazol-2-yl)-2,5-diphenyltetrazolium bromide (MTT) and 4',6-diamidino-2-phenylindole (DAPI) were obtained from Sigma-Aldrich Co. (St. Louis, MO, USA). McCoy's 5A (modified) medium, fetal bovine serum (FBS), trypsin-EDTA, penicillin/streptomycin, Fluo-3/AM, 2,7-dichlorodihydrofluorescein diacetate $\left(\mathrm{H}_{2} \mathrm{DCFDA}\right)$ and 3,3'-dihexyloxacarbocyanine iodide $\left[\mathrm{DiOC}_{6}(3)\right]$ were obtained from Thermo Fisher Scientific Inc. (Waltham, MA, USA). Pan-caspase inhibitor (Z-VAD-FMK), caspase-3 inhibitor (Z-DEVD-FMK), caspase-8 inhibitor (Z-IETD-FMK) and caspase-9 inhibitor (Z-LEHD-FMK) were purchased from R\&D Systems (Minneapolis, MN, USA). Primary antibodies (anti-Fas/CD95, anti-FasL, anti-cytochrome $c$, anti-Apaf-1, anti-GADD153 and anti-GRP78 and anti- $\beta$-actin) and second antibodies [goat anti-rabbit IgG-horseradish peroxidase (HRP) and goat anti-mouse IgG-HRP] were obtained from Santa Cruz Biotechnology (Santa Cruz, CA, USA).

Cell culture. Human osteogenic sarcoma U-2 OS cell line was obtained from the Bioresource Collection and Research Center (BCRC; Hsinchu, Taiwan) and cultured in $75-\mathrm{cm}^{2}$ tissue culture flasks with McCoy's 5A (modified) medium with $10 \%$ FBS, 100 Units $/ \mathrm{ml}$ penicillin and $100 \mu \mathrm{g} / \mathrm{ml}$ streptomycin at $37^{\circ} \mathrm{C}$ with $5 \% \mathrm{CO}_{2}$.

Cell viability and morphological observation. U-2 OS cells $\left(1 \times 10^{4}\right.$ cells/well) in a 96 -well plate were individually pretreated with or without $15 \mu \mathrm{M}$ specific caspase inhibitors (Z-VAD-FMK, Z-IETD-FMK, Z-LEHD-FMK and Z-DEVD-FMK) for $2 \mathrm{~h}$ and then exposed to $0,50,100,150$ and $200 \mu \mathrm{M}$ of $\mathrm{GdCl}_{3}$ for $24 \mathrm{~h}$. After challenge, cell viability was assessed by an MTT assay, as previously reported by $\mathrm{Lu}$ et al (24). The $\mathrm{GdCl}_{3}$-treated cells were examined for apoptosis and photographed utilizing a phase-contrast microscope, as previously described (25).

Apoptosis by TUNEL and DAPI staining. U-2 OS cells $\left(2 \times 10^{5}\right.$ cells/well) in 24-well plates were treated with $0,50,100,150$ and $200 \mu \mathrm{M}$ of $\mathrm{GdCl}_{3}$ for $24 \mathrm{~h}$. Apoptotic DNA breaks were labeled with the In Situ Cell Death Detection kit, Fluorescein (Roche Diagnostics GmbH, Mannheim, Germany) according to the vendor's protocol, and the terminal deoxynucleotidyl transferase (TdT)-mediated dUTP nick-end labeling (TUNEL) positive cells were monitored using a BD FACSCalibur flow cytometry (BD Biosciences, San Jose, CA, USA) and BD CellQuest Pro Software (BD Biosciences), as previously described (26). DAPI dye was used to countstain condensation nuclei (a characteristic of apoptosis) in U-2 OS cells with or without $200 \mu \mathrm{M} \mathrm{GdCl}_{3}$ for $24 \mathrm{~h}$, as detailed by previous studies $(27,28)$.

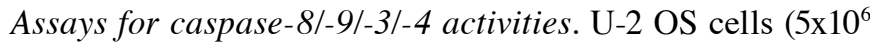
cells per 75T flask) were exposed to $0,50,100,150$ and $200 \mu \mathrm{M}$ of $\mathrm{GdCl}_{3}$ for $24 \mathrm{~h}$. The cell lysates were harvested and assessed subsequently in accordance with the manufacturer's instruction [caspase-8, caspase- 9 and caspase-3 colorimetric assay kits (R\&D System Inc.) and caspase-4 colorimetric assay kit (BioVision Incorporated, Milpitas, CA, USA)].

Determinations of intracellular $\mathrm{Ca}^{2+}, \mathrm{ROS}$ and $\triangle \Psi \mathrm{m}$ levels by flow cytometry. U-2 OS cells $\left(2 \times 10^{5}\right.$ cells/well $)$ were incubated with or without 50,100,150 and $200 \mu \mathrm{M}$ of $\mathrm{GdCl}_{3}$ for $6 \mathrm{~h}$. Cells were harvested and individually stained with $3 \mu \mathrm{g} / \mathrm{ml}$ Fluo-3/AM for cytoplasmic $\mathrm{Ca}^{2+}$, ROS indicator (5 $\left.\mu \mathrm{M} \mathrm{H}_{2} \mathrm{DCFDA}\right)$ and $\Delta \Psi \mathrm{m}$ probe $\left[4 \mathrm{nM} \mathrm{DiOC}_{6}(3)\right]$ at $37^{\circ} \mathrm{C}$ for $30 \mathrm{~min}$. The mean fluorescence intensity (MFI) was quantified by BD CellQuest Pro software (BD Biosciences) before analysis by flow cytometry, as previously described $(13,26)$.

Western blot analysis. U-2 OS cells $\left(5 \times 10^{6}\right.$ cells/75T flask $)$ were treated in the presence and absence of $0,50,100,150$ and $200 \mu \mathrm{M}$ of $\mathrm{GdCl}_{3}$ for $24 \mathrm{~h}$. Cell lysates were collected, and protein was fractionated on SDS-polyacrylamide gel electrophoresis (PAGE) after being mixed with protein loading dye and boiled, as previously described $(14,29)$. The membrane (iBlot Transfer Stack, PVDF regular; Thermo Fisher Scientific Inc.) was probed with antibodies against Fas, FasL, cytochrome $c$, Apaf-1, GADD153 and GRP78, respectively. All blots were normalized to $\beta$-actin signal, and each signal was quantified with NIH ImageJ program for Windows (National Institutes of Health, Bethesda, MD, USA).

Statistical analysis. Statistical calculations of the data for comparisons of two mean values were obtained using Student's $\mathrm{t}$-test. Statistical significance was set at $\mathrm{P}<0.05$. All data were expressed as mean \pm standard deviation (SD) of three independent experiments. 

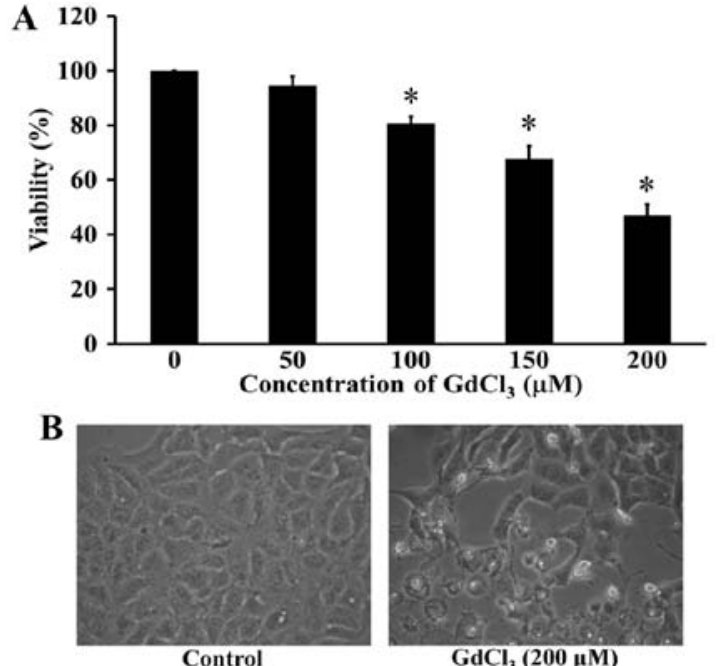

Figure 1. Effects of gadolinium chloride $\left(\mathrm{GdCl}_{3}\right)$ on cell viability in human osteosarcoma U-2 OS cells. Cells were treated with $\mathrm{GdCl}_{3}(0,50,100,150$ and $200 \mu \mathrm{M}$ ) for $24 \mathrm{~h}$. (A) Cell viability was determined by an MTT assay, and data are presented as the mean $\pm \mathrm{SD}(\mathrm{n}=3)$. ${ }^{*} \mathrm{P}<0.05$ vs. untreated control. (B) Cells in response to $200 \mu \mathrm{M} \mathrm{GdCl}_{3}$ showed morphological changes and were photographed from three independent experiments.

\section{Results}

$\mathrm{GdCl}_{3}$ reduces cell viability of human osteosarcoma $U-2$ OS cells. Cells were treated with $\mathrm{GdCl}_{3}$ at the different concentrations from 0 to $200 \mu \mathrm{M}$ for $24 \mathrm{~h}$. The number of viable cells was assessed by the MTT method. The cell viability was markedly decreased in $\mathrm{GdCl}_{3}$-treated U-2 OS cells in concentration-dependent manner (Fig. 1A). The inhibitory concentration $50 \%\left(\mathrm{IC}_{50}\right)$ for $\mathrm{U}-2$ OS cells was $198.26 \pm 1.69 \mu \mathrm{M} . \mathrm{GdCl}_{3}$ at $200 \mu \mathrm{M}$ led to the morphological changes and apoptotic cell shrinkage in U-2 OS cells. Also, $\mathrm{GdCl}_{3}$-treated cells were detached from the surface, and some cell debris was observed, whereas the untreated control cells were well spread (Fig. 1B). These findings suggested that $\mathrm{GdCl}_{3}$ possessed cytotoxic effect on human osteosarcoma U-2 OS cells.

$\mathrm{GdCl}_{3}$ provokes $\mathrm{U}-2$ OS cell apoptosis. To explore whether $\mathrm{GdCl}_{3}$ induces U-2 OS cell death through an apoptotic mechanism, TUNEL assay was used for detecting DNA fragmentation in apoptotic cells. $\mathrm{GdCl}_{3}$ markedly stimulated cell apoptosis (TUNEL positive cells) in comparison with control cells (Fig. 2A), and this effect was concentration-dependent (Fig. 2B). Furthermore, apoptotic DNA condensation by DAPI stain was shown in $\mathrm{GdCl}_{3}$-treated U-2 OS cells (Fig. 2A). Our results indicated that $\mathrm{GdCl}_{3}$ provoked apoptotic cell death in U-2 OS cells.

$\mathrm{GdCl}_{3}$ stimulates the activities of caspase-3, caspase-8, and caspase-9 in U-2 OS cells. To clarify the mechanism of $\mathrm{GdCl}_{3}$-induced apoptosis, we further individually investigated the activities of caspase-3, caspase-8, and caspase-9 in U-2 OS cells prior to $\mathrm{GdCl}_{3}$ challenge. The activities of caspase- 3 (Fig. 3A), caspase-8 (Fig. 3B) and caspase-9 (Fig. 3C) were increased after $\mathrm{GdCl}_{3}$ exposure in a concentration-dependent manner. Pretreatment of cells with pan-caspase inhibitor (Z-VAD-FMK) (Fig. 4A), specific inhibitors to caspase-3,
A
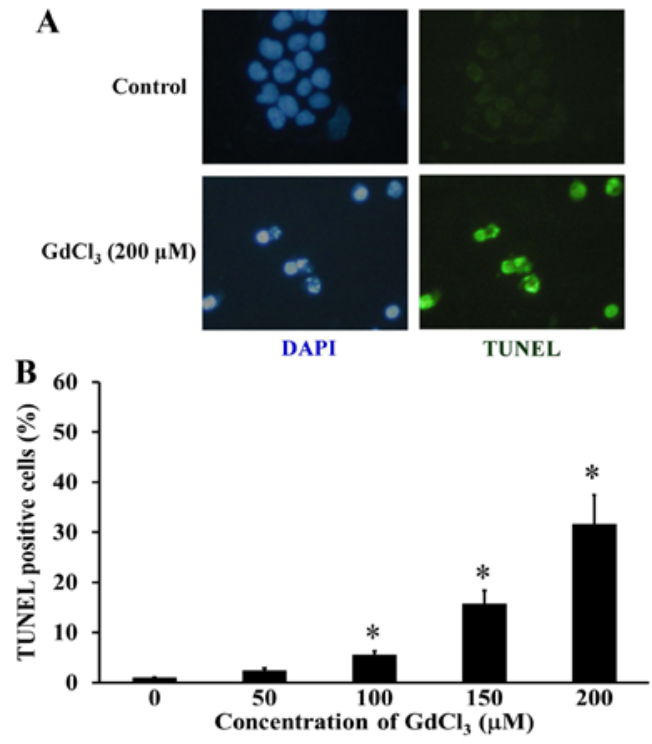

Figure 2. Effects of gadolinium chloride $\left(\mathrm{GdCl}_{3}\right)$ on apoptosis in $\mathrm{U}-2 \mathrm{OS}$ cells. Cells were exposed to $200 \mu \mathrm{M} \mathrm{GdCl}_{3}$ for $24 \mathrm{~h}$ and then harvested to determine by TUNEL assay kit as described in Materials and methods. (A) Immunofluorescence staining of apoptotic cells in $\mathrm{GdCl}_{3}$-treated cells was observed, and 4',6-diamidino-2-phenylindole (DAPI) was used to counterstain the nuclei. (B) TUNEL positive cells were quantified, and data are presented as the mean $\pm \mathrm{SD}(\mathrm{n}=3)$. ${ }^{*} \mathrm{P}<0.05$ vs. untreated control.
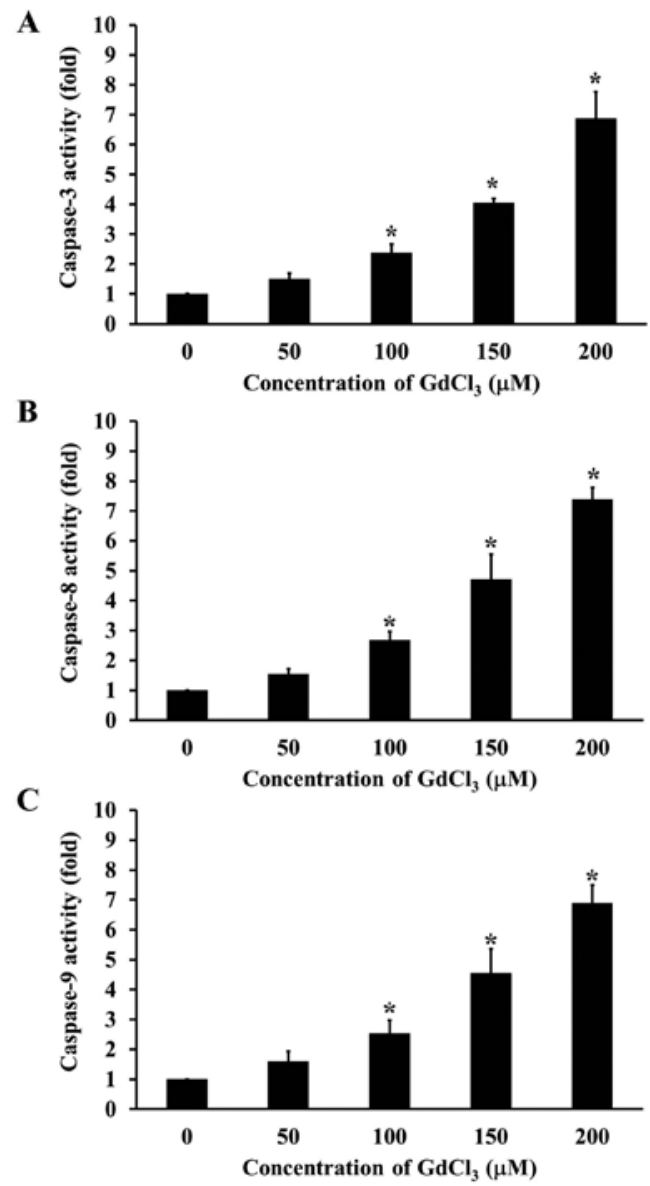

Figure 3. Effects of gadolinium chloride $\left(\mathrm{GdCl}_{3}\right)$ on caspase-3, caspase-8, and caspase- 9 activities in U-2 OS cells. Cells were incubated with $0,50,100$, 150 and $200 \mu \mathrm{M}$ of $\mathrm{GdCl}_{3}$ for $24 \mathrm{~h}$. The cell lysates were harvested to assess (A) caspase-3, (B) caspase-8 and (C) caspase- 9 activities as described in Materials and methods. Data are presented as the mean $\pm \mathrm{SD}(\mathrm{n}=3)$. ${ }^{*} \mathrm{P}<0.05$ vs. untreated control 


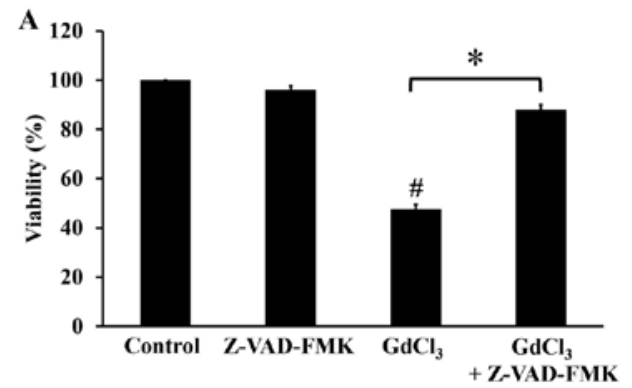

B

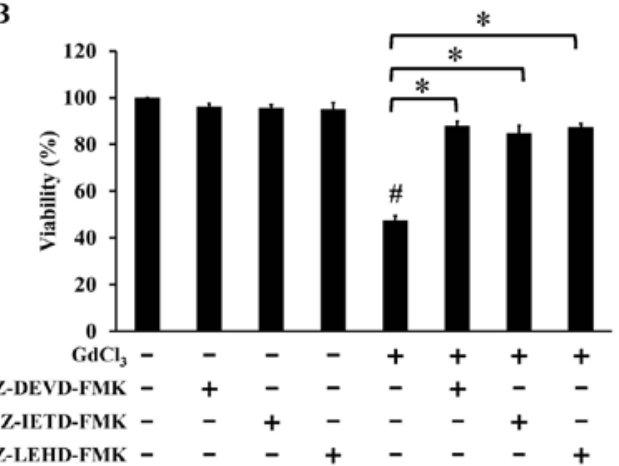

Figure 4. Effects of caspase inhibitors on U-2 OS cells after gadolinium chloride $\left(\mathrm{GdCl}_{3}\right)$ treatment. Cells were exposed to $200 \mu \mathrm{M} \mathrm{GdCl}_{3}$ for $24 \mathrm{~h}$ after pretreatment with or without $15 \mu \mathrm{M}$ of pan-caspase inhibitor (Z-VAD-FMK), caspase-3 inhibitor (Z-DEVD-FMK), caspase-8 inhibitor (Z-IETD-FMK) and caspase-9 inhibitor (Z-LEHD-FMK) for $2 \mathrm{~h}$. Pretreatment with (A) Z-VAD-FMK and (B) inhibitors of caspase-3, caspase- 8 and caspase-9, respectively, cell viability was carried out by an MTT assay, and data are presented as the mean $\pm \mathrm{SD}(\mathrm{n}=3) .{ }^{*} \mathrm{P}<0.05$ vs. untreaed control; ${ }^{*} \mathrm{P}<0.05$ vs. $\mathrm{GdCl}_{3}$-treated only.

caspase-8, and caspase-9 (Fig. 4B) significantly prevented the $\mathrm{GdCl}_{3}$-induced cell apoptosis. Our results suggest that the caspase cascade-dependent pathway is important in $\mathrm{GdCl}_{3}$-induced apoptotic death in U-2 OS cells.

$\mathrm{GdCl}_{3}$ increases cytoplasmic $\mathrm{Ca}^{2+}$ level and stimulated the activity of caspase-4 in U-2 OS cells. To further elucidate the possible signaling of $\mathrm{GdCl}_{3}$-induced apoptosis in U-2 OS cells, we determined intracellular $\mathrm{Ca}^{2+}$ levels and caspase- 4 activity by flow cytometric analysis and caspase activity assay, respectively. Cells were treated with 50, 100, 150 and $200 \mu \mathrm{M}$ of $\mathrm{GdCl}_{3}$ for $24 \mathrm{~h}$, and our data demonstrated that $\mathrm{GdCl}_{3}$ significantly increased intracellular $\mathrm{Ca}^{2+}$ levels (Fig. 5A). In addition, caspase- 4 activity was concentrationdependently increased in U-2 OS cells after $\mathrm{GdCl}_{3}$ treatment (Fig. 5B). These results showed that $\mathrm{GdCl}_{3}$ induced apoptotic response through cytoplasmic $\mathrm{Ca}^{2+}$ level and ER stress-mediated pathway.

$\mathrm{GdCl}_{3}$ stimulates the ROS production and loss of $\triangle \Psi \mathrm{m}$ level in $U-2$ OS cells. To examine the effect of $\mathrm{GdCl}_{3}$ on ROS production and $\Delta \Psi \mathrm{m}$ levels in U-2 OS cells, the specific fluorescence probes were individually used to detect the levels of ROS and $\Delta \Psi \mathrm{m} . \mathrm{GdCl}_{3}$ concentration-dependently increased intracellular ROS level in U-2 OS cells (Fig. 6A). $\mathrm{GdCl}_{3}$ disrupted $\Delta \Psi \mathrm{m}$ level in U-2 OS cells in a concentration-dependent manner (Fig. 6B). These results suggested that $\mathrm{GdCl}_{3}$ triggered apoptosis in U-2 OS cells by way of the ROS and mitochondria-dependent signaling.
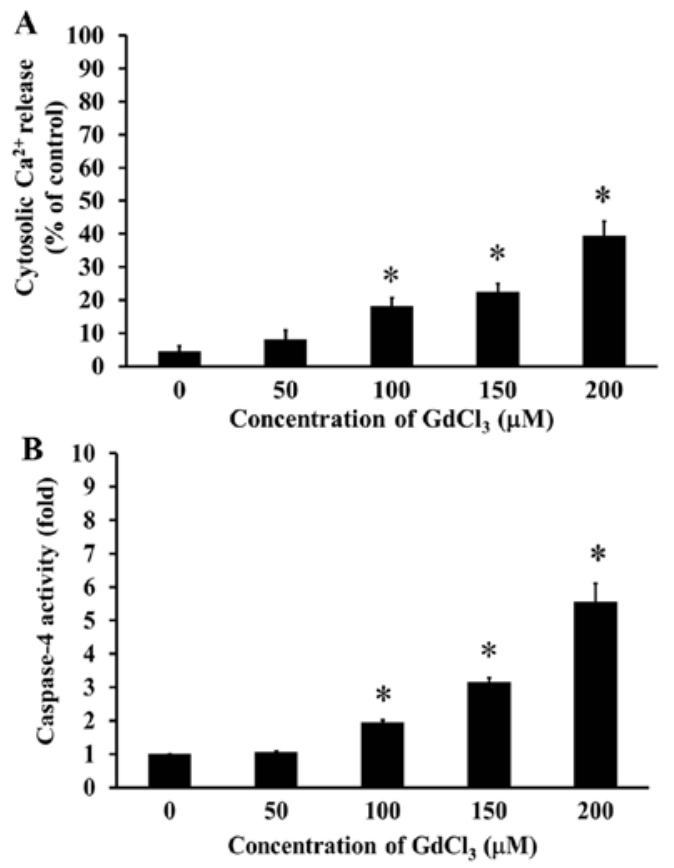

Figure 5. Effects of gadolinium chloride $\left(\mathrm{GdCl}_{3}\right)$ on cytoplasmic $\mathrm{Ca}^{2+}$ levels and caspase- 4 activity in U-2 OS cells. Cells were exposed to $0,50,100,150$ and $200 \mu \mathrm{M}$ of $\mathrm{GdCl}_{3}$ for $24 \mathrm{~h}$ and then collected to employ (A) intracellular $\mathrm{Ca}^{2+}$ levels after stained with $3 \mu \mathrm{g} / \mathrm{ml}$ Fluo-3/AM by flow cytometry and (B) caspase-4 level as described in Materials and methods. Data are presented as the mean $\pm \mathrm{SD}(\mathrm{n}=3)$. ${ }^{*} \mathrm{P}<0.05$ vs. untreated control.

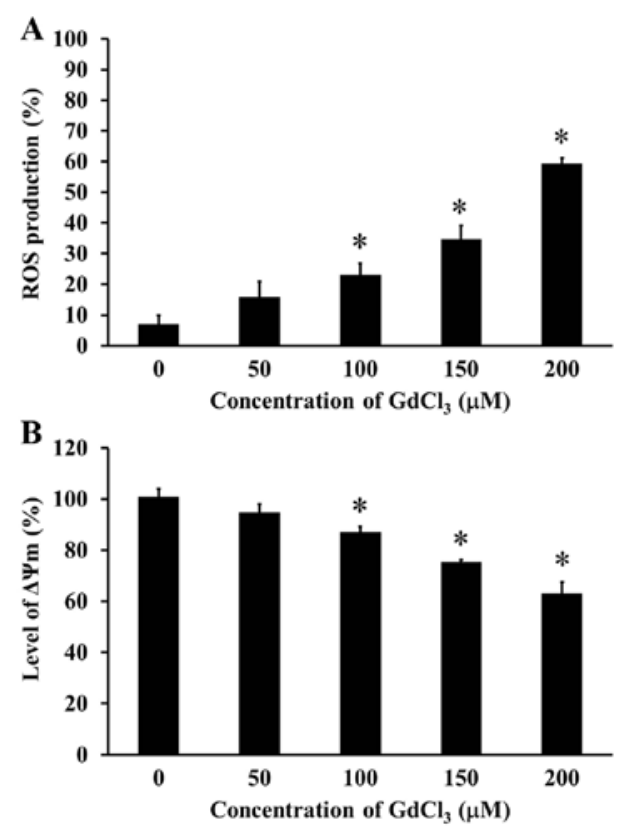

Figure 6. Effects of gadolinium chloride $\left(\mathrm{GdCl}_{3}\right)$ on ROS and $\Delta \Psi \mathrm{m}$ in U-2 OS cells. Cells were incubated with $0,50,100,150$ and $200 \mu \mathrm{M}$ of $\mathrm{GdCl}_{3}$ for $24 \mathrm{~h}$. (A) ROS level was assessed by staining with $5 \mu \mathrm{M} \mathrm{H}_{2}$ DCFDA, and (B) the disruption of $\Delta \Psi \mathrm{m}$ was measured by using the fluorochrome $4 \mathrm{nM}$ $\mathrm{DiOC}_{6}(3)$ by flow cytometry. Data are presented as the mean $\pm \mathrm{SD}(\mathrm{n}=3)$. ${ }^{*} \mathrm{P}<0.05$ vs. untreated control.

$\mathrm{GdCl}_{3}$ alters the levels of apoptosis-related proteins in U-2 OS cells. In more detail, in the molecular mechanisms of apoptotic pathway, we investigated these related protein levels by western blotting. The levels of Fas, FasL, cytochrome $c$, Apaf-1, 


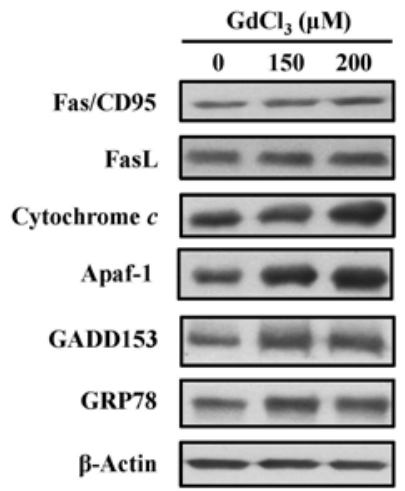

Figure 7. Effects of gadolinium chloride $\left(\mathrm{GdCl}_{3}\right)$ on the levels of apoptotic relative proteins in U-2 OS cells. Cells were exposed to 150 and $200 \mu \mathrm{M}$ of $\mathrm{GdCl}_{3}$ for $24 \mathrm{~h}$, and whole-cell lysates were prepared and subjected to western blot analysis and to blot using the specific antibodies (Fas/CD95, FasL, cytochrome $c$, Apaf-1, GADD153 and GRP78). $\beta$-actin served as the loading control to ensure equal loading.

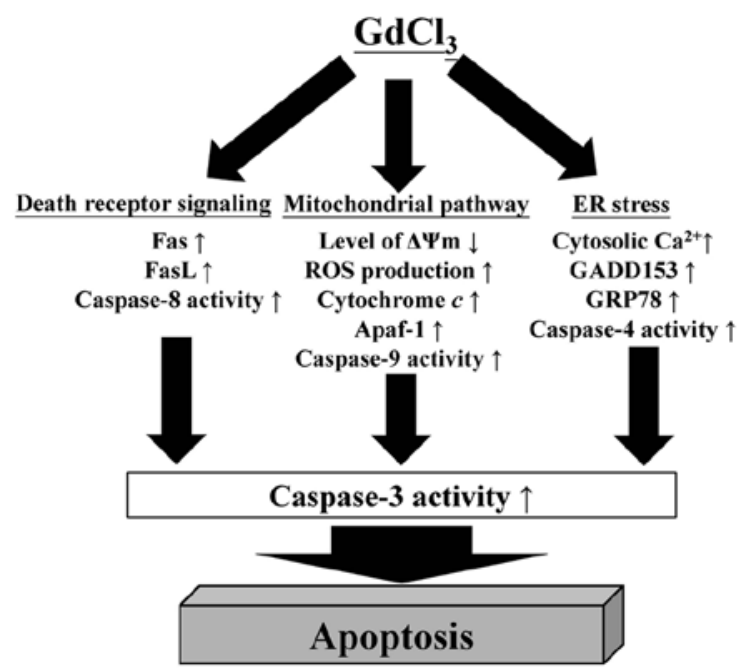

Figure 8 . The proposed pathway indicates the three major apoptosis signaling (death receptor, mitochondria and ER stress pathways) for gadolinium chloride $\left(\mathrm{GdCl}_{3}\right)$-induced apoptosis in human osteosarcoma U-2 OS cells.

GADD153 and GRP78 were increased in $\mathrm{GdCl}_{3}$-treated cells (Fig. 7). These results suggested that $\mathrm{GdCl}_{3}$-induced apoptotic action might be involved in death receptor-mediated signaling, mitochondria-dependent pathway and ER stress in U-2 OS cells.

\section{Discussion}

Lanthanide ( $\mathrm{Ln}$ ) compounds have been shown to possess contrary effects on anticancer activities such as promotion of cell cycle progression and cell growth by lower concentration treatment but induction of apoptosis and suppression of cell proliferation at higher dosing $(16,18,19)$. Our results indicated that high concentration of $\mathrm{GdCl}_{3}$ caused apoptotic U-2 OS cell death (Fig. 1). This is first to report that the MRI contrast agent $\mathrm{GdCl}_{3}$ can be successfully applied to induce apoptosis of human osteosarcoma cells. Moreover, an increase of TUNEL positive cells (Fig. 2), activation of caspase-3, caspase-8, caspase-9 (Fig. 3) and caspase-4 (Fig. 5B) was found to suggest that $\mathrm{GdCl}_{3}$ caused apoptosis of U-2 OS through multiple pathways.
It is well know that $\mathrm{Gd}^{3+}$, like other Ln ions, caused different effects depending on the type of target cells $(30,31)$. In NIH $3 \mathrm{~T} 3$ cells, $\mathrm{GdCl}_{3}$ at the concentrations of $<100 \mu \mathrm{M}$ exerts proliferation-promoting effect and activation of extracellular signal-regulated kinase (ERK) and phosphoinositide 3-kinase (PI3K) signaling pathways (31). Gadolinium provokes cell apoptosis through mitochondrial pathway and oxidative stress in L-02 normal liver cells (32).

Ye et al (22) reported that $\mathrm{GdCl}_{3}$ induces HepG2 cell apoptosis through mitochondrial and death receptor-dependent pathways. Similarly, our results also demonstrated that $\mathrm{GdCl}_{3}$ induced apoptosis through death receptor and mitochondria-dependent pathways in U-2 OS cells. In the present study, we found that $\mathrm{GdCl}_{3}$ increased the ROS production and decreased the levels of $\Delta \Psi \mathrm{m}$ (Fig. 6), and western blot analysis showed that $\mathrm{GdCl}_{3}$ treatment resulted in an increase of Fas/CD95, FasL, cytochrome $c$ and Apaf-1 protein expression in U-2 OS cells (Fig. 7). Thus, we suggest that $\mathrm{GdCl}_{3}$-induced cell death may be mediated via extrinsic and intrinsic apoptotic pathway in U-2 OS cells.

Calcium $\left(\mathrm{Ca}^{2+}\right)$ regulates cell proliferation, apoptosis or differentiation and plays a pivotal role in carcinogenesis and progression (33). Xia et al (34) has indicated that gadoliniuminduced oxidative stress causes ER stress in rat cortical neurons. Feng et al (35) also showed that gadolinium triggers unfolded protein responses (UPRs) in primary cultured rat cortical astrocytes through increasing an influx of extracellular $\mathrm{Ca}^{2+}$ level. However, there is no available report regarding $\mathrm{GdCl}_{3}$-induced ER stress in U-2 OS cells. In the present study, we investigated the $\mathrm{GdCl}_{3}$-induced ER stress in apoptotic mechanism of U-2 OS cells. Our findings demonstrated that the increased levels of GADD153 and GRP78 were followed by releasing $\mathrm{Ca}^{2+}$ from ER and activating caspase- 4 activity (Fig. 5), finally leading to ER stress and cell apoptosis. Our results revealed that the activation of ER stress signaling contribute to $\mathrm{GdCl}_{3}$-induced apoptosis in $\mathrm{U}-2 \mathrm{OS}$ cells.

In conclusion, we found that $\mathrm{GdCl}_{3}$ exhibits direct anticancer activity and triggers suppression of tumor cell proliferation in human osteosarcoma cells. $\mathrm{GdCl}_{3}$ provoked U-2 OS cell apoptosis by the way of the death receptor, mitochondria-dependent and ER stress pathways. The proposed pathway of $\mathrm{GdCl}_{3}$-induced apoptosis of human osteosarcoma U-2 OS cells is showing in Fig. 8. Taken together, our findings provide important possible molecular mechanism against osteosarcoma of $\mathrm{GdCl}_{3}$, showing that $\mathrm{GdClv}$ may be a promising anti-osteosarcoma drug.

\section{Acknowledgements}

The present study was financially supported by a research grant (no. SKH-TMU-104-01) from the Shin-Kong Wu Ho-Su Memorial Hospital, Taipei, Taiwan.

\section{References}

1. Duong LM and Richardson LC: Descriptive epidemiology of malignant primary osteosarcoma using population-based registries, United States, 1999-2008. J Registry Manag 40: 59-64, 2013.

2. Ottaviani G and Jaffe N: The epidemiology of osteosarcoma. Cancer Treat Res 152: 3-13, 2009. 
3. Savage SA and Mirabello L: Using epidemiology and genomics to understand osteosarcoma etiology. Sarcoma 2011: 548151, 2011.

4. Salas S, Jézéquel P, Campion L, Deville JL, Chibon F, Bartoli C, Gentet JC, Charbonnel C, Gouraud W, Voutsinos-Porche B, et al: Molecular characterization of the response to chemotherapy in conventional osteosarcomas: Predictive value of HSD17B10 and IFITM2. Int J Cancer 125: 851-860, 2009.

5. Venkatramani R, Murray J, Helman L, Meyer W, Hicks MJ Krance R, Lau C, Jo E and Chintagumpala M: Risk-based therapy for localized osteosarcoma. Pediatr Blood Cancer 63: 412-417, 2016.

6. Padma VV: An overview of targeted cancer therapy. Biomedicine (Taipei) 5: 19, 2015.

7. Alfranca A, Martinez-Cruzado L, Tornin J, Abarrategi A Amaral T, de Alava E, Menendez P, Garcia-Castro J and Rodriguez R: Bone microenvironment signals in osteosarcoma development. Cell Mol Life Sci 72: 3097-3113, 2015.

8. Bian DL, Wang XM, Huang K, Zhai QX, Yu GB and Wu CH: Expression and regulatory effects of microRNA-182 in osteosarcoma cells: A pilot study. Oncol Lett 11: 3040-3048, 2016.

9. Ling H, Vincent K, Pichler M, Fodde R, Berindan-Neagoe I, Slack FJ and Calin GA: Junk DNA and the long non-coding RNA twist in cancer genetics. Oncogene 34: 5003-5011, 2015.

10. Ouyang L, Shi Z, Zhao S, Wang FT, Zhou TT, Liu B and Bao JK: Programmed cell death pathways in cancer: A review of apoptosis, autophagy and programmed necrosis. Cell Prolif 45: 487-498, 2012.

11. Elmore S: Apoptosis: A review of programmed cell death. Toxicol Pathol 35: 495-516, 2007.

12. Szegezdi E, Logue SE, Gorman AM and Samali A: Mediators of endoplasmic reticulum stress-induced apoptosis. EMBO Rep 7: 880-885, 2006.

13. Lu CC, Yang JS, Chiang JH, Hour MJ, Lin KL, Lee TH and Chung JG: Cell death caused by quinazolinone HMJ-38 challenge in oral carcinoma CAL 27 cells: Dissections of endoplasmic reticulum stress, mitochondrial dysfunction and tumor xenografts. Biochim Biophys Acta 1840: 2310-2320, 2014.

14. Lee CF, Yang JS, Tsai FJ, Chiang NN, Lu CC, Huang YS, Chen C and Chen FA: Kaempferol induces ATM/p53-mediated death receptor and mitochondrial apoptosis in human umbilical vein endothelial cells. Int J Oncol 48: 2007-2014, 2016.

15. Wang G, Peng Q and Li Y: Lanthanide-doped nanocrystals: Synthesis, optical-magnetic properties, and applications. Acc Chem Res 44: 322-332, 2011.

16. Pang X, Li D and Peng A: Application of rare-earth elements in the agriculture of China and its environmental behavior in soil. Environ Sci Pollut Res Int 9: 143-148, 2002.

17. Long XH, Yang PY, Liu Q, Yao J, Wang Y, He GH, Hong GY and Ni JZ: Metabolomic profiles delineate potential roles for gadolinium chloride in the proliferation or inhibition of $\mathrm{HeLa}$ cells. Biometals 24: 663-677, 2011.

18. Zhou Z and Lu ZR: Gadolinium-based contrast agents for magnetic resonance cancer imaging. Wiley Interdiscip Rev Nanomed Nanobiotechnol 5: 1-18, 2013

19. Strijkers GJ, Mulder WJ, van Tilborg GA and Nicolay K: MRI contrast agents: Current status and future perspectives. Anticancer Agents Med Chem 7: 291-305, 2007.

20. Pintaske J, Martirosian P, Graf H, Erb G, Lodemann KP, Claussen CD and Schick F: Relaxivity of gadopentetate dimeglumine (Magnevist), gadobutrol (Gadovist), and gadobenate dimeglumine (MultiHance) in human blood plasma at 0.2, 1.5, and 3 tesla. Invest Radiol 41: 213-221, 2006.
21. Edelman MJ, Otterson G, Leach J, Malpass T, Salgia R, Jones D, Mody TD and Govindan R: Multicenter phase II trial of Motexafin gadolinium and pemetrexed for second-line treatment in patients with non-small cell lung cancer. J Thorac Oncol 6: 786-789, 2011.

22. Ye L, Shi Z, Liu H, Yang X and Wang $\mathrm{K}: \mathrm{GdCl}_{3}$ induced Hep G2 cell death through mitochondrial and external death pathways without significant elevation of ROS generation. Biol Trace Elem Res 151: 148-155, 2013.

23. Rose ML, Bradford BU, Germolec DR, Lin M, Tsukamoto H and Thurman RG: Gadolinium chloride-induced hepatocyte proliferation is prevented by antibodies to tumor necrosis factor alpha. Toxicol Appl Pharmacol 170: 39-45, 2001

24. Lu CC, Yang SH, Hsia SM, Wu CH and Yen GC: Inhibitory effects of Phyllanthus emblica L. on hepatic steatosis and liver fibrosis in vitro. J Funct Foods 20: 20-30, 2016.

25. Hui K, Yang Y, Shi K, Luo H, Duan J, An J, Wu P, Ci Y, Shi L and $\mathrm{Xu}$ C: The p38 MAPK-regulated PKD1/CREB/Bcl-2 pathway contributes to selenite-induced colorectal cancer cell apoptosis in vitro and in vivo. Cancer Lett 354: 189-199, 2014.

26. Chiang JH, Yang JS, Lu CC, Hour MJ, Chang SJ, Lee TH and Chung JG: Newly synthesized quinazolinone HMJ-38 suppresses angiogenetic responses and triggers human umbilical vein endothelial cell apoptosis through p53-modulated Fas/death receptor signaling. Toxicol Appl Pharmacol 269: 150-162, 2013.

27. Lu CC, Yang JS, Chiang JH, Hour MJ, Lin KL, Lin JJ, Huang WW, Tsuzuki M, Lee TH and Chung JG: Novel quinazolinone MJ-29 triggers endoplasmic reticulum stress and intrinsic apoptosis in murine leukemia WEHI-3 cells and inhibits leukemic mice. PLoS One 7: e36831, 2012.

28. Chiang JH, Yang JS, Lu CC, Hour MJ, Liu KC, Lin JH, Lee TH and Chung JG: Effect of DNA damage response by quinazolinone analogue HMJ-38 on human umbilical vein endothelial cells: Evidence for $\gamma \mathrm{H} 2 \mathrm{~A} . \mathrm{X}$ and DNA-PK-dependent pathway. Hum Exp Toxicol 33: 590-601, 2014

29. Yang JS, Hour MJ, Huang WW, Lin KL, Kuo SC and Chung JG: MJ-29 inhibits tubulin polymerization, induces mitotic arrest, and triggers apoptosis via cyclin-dependent kinase 1-mediated Bcl-2 phosphorylation in human leukemia U937 cells. J Pharmacol Exp Ther 334: 477-488, 2010.

30. Wolfbeis OS: An overview of nanoparticles commonly used in fluorescent bioimaging. Chem Soc Rev 44: 4743-4768, 2015.

31. Shen L, Yang A, Yao P, Sun X, Chen C, Mo C, Shi L, Chen Y and Liu Q: Gadolinium promoted proliferation in mouse embryo fibroblast NIH3T3 cells through Rac and PI3K/Akt signaling pathways. Biometals 27: 753-762, 2014.

32. Ye LH, Shi Z, Liu HX, Yang XD and Wang K: Gadolinium induced apoptosis of human embryo liver L02 cell line by ROS-mediated AIF pathway. J Rare Earths 29: 178-184, 2011

33. Resende RR, Andrade LM, Oliveira AG, Guimarães ES, Guatimosim S and Leite MF: Nucleoplasmic calcium signaling and cell proliferation: Calcium signaling in the nucleus. Cell Commun Signal 11: 14, 2013.

34. Xia Q, Feng X, Huang H, Du L, Yang X and Wang K: Gadoliniuminduced oxidative stress triggers endoplasmic reticulum stress in rat cortical neurons. J Neurochem 117: 38-47, 2011.

35. Feng XD, Xia Q, Yuan L, Huang HF, Yang XD and Wang K: Gadolinium triggers unfolded protein responses (UPRs) in primary cultured rat cortical astrocytes via promotion of an influx of extracellular $\mathrm{Ca}^{2+}$. Cell Biol Toxicol 27: 1-12, 2011. 